\title{
TANGGUNG JAWAB KELUARGA DALAM PENDIDIKAN ANAK DI ERA KOSMOPOLITAN \\ (Tela'ah Tafsir Kontemporer Atas Surat At-Tahrim Ayat 6)
}

\author{
Arie Sulistyoko \\ Universitas Islam Negeri Antasari Banjarmasin \\ 085251101107
}

\begin{abstract}
In an effort to produce a strong and quality future generation, there needs to be consistent and continuous efforts from parents in carrying out the task of nurturing, nurturing and educating their children physically and mentally until the child is mature and / or can stand alone, where the task this is the obligation of parents. The issue of child care and care is a problem related to the protection of children's own welfare in an effort to improve the quality of children in their growth, and prevent the neglect and unfair treatment to realize children as humans who are whole, resilient, intelligent and virtuous. So, shelter for children is parents. in the lives of people everywhere, families are the smallest unit with a very large role. A very big role is caused, because the family has a very important function in the continuity of people's lives. The process of knowing the rules and values adopted, for the first time was obtained in the family.
\end{abstract}

Keywords: Responsibility, Family, Children, Education

\begin{abstract}
Abstrak
Dalam upaya menghasilkan generasi masa depan yang kuat dan berkualitas, perlu ada upaya yang konsisten dan berkelanjutan dari orang tua dalam menjalankan tugas mengasuh, mengasuh dan mendidik anak-anak mereka secara fisik dan mental hingga anak sudah dewasa dan / atau bisa berdiri sendiri, dimana tugas ini adalah kewajiban orang tua. Masalah pengasuhan dan perawatan anak adalah masalah yang berkaitan dengan perlindungan kesejahteraan anak sendiri dalam upaya untuk meningkatkan kualitas anak-anak dalam pertumbuhan mereka, dan mencegah pengabaian dan perlakuan tidak adil untuk mewujudkan anak-anak sebagai manusia yang utuh, ulet, cerdas dan berbudi luhur. Maka, tempat penampungan untuk anak-anak adalah orang tua. Dalam kehidupan orang-orang di manamana, keluarga adalah unit terkecil yang perannya sangat besar. Peran yang sangat besar disebabkan, karena keluarga memiliki fungsi yang sangat penting dalam kelangsungan kehidupan masyarakat. Proses mengetahui aturan dan nilai yang diadopsi, untuk pertama kalinya diperoleh dalam keluarga.
\end{abstract}

Kata kunci: Tanggung Jawab, Keluarga, Anak, Pendidikan.

\section{PENDAHULUAN}

Pernikahan adalah peristiwa yang menciptakan kewajiban dan hak bagi mereka yang melaksanakannya. Salah satu kewajiban dan hak suami dan istri dalam pernikahan adalah untuk merawat, merawat, merawat, dan melindungi 
bayi mereka hingga dewasa. Anak adalah anugerah dari Tuhan yang sangat besar dan membuat mandat bagi orang tua untuk merawatnya dengan baik sehingga berguna bagi bangsa dan negara. Karena itu, orang tua harus mendidik, mengasuh, melindungi, memelihara dan mengembangkan anak. ${ }^{1}$

Dadang Hawari menyatakan bahwa pertumbuhan dan perkembangan kejiwaan anak-anak (intelektual dan mental emosional), IQ dan EQ, sangat dipengaruhi oleh sikap, cara dan kepribadian orang tua dalam mengasuh, mengasuh dan mendidik anak-anak mereka. Sebab, dalam masa pertumbuhan dan perkembangan anak ada proses imitasi dan identifikasi anak terhadap kedua orang tua. Oleh karena itu, sangat tepat bagi orang tua untuk mengetahui beberapa aspek pengetahuan dasar yang penting dalam kaitannya dengan pertumbuhan dan perkembangan anak-anak. Perkembangan anak membutuhkan dua jenis makanan dan kebutuhan bergizi, yaitu makanan kelahiran, dan makanan mental, dalam bentuk: cinta, perhatian, pendidikan, dan bimbingan psikologis (non-fisik) yang dapat diberikan orang tua dalam kehidupan sehari-hari mereka. Batista mengatakan warisan paling berharga yang dapat diberikan orang tua kepada anak-anak mereka adalah beberapa menit setiap hari.2

Ketika disortir, tugas pertama manusia adalah memiliki anak dan bertambah jumlahnya. Manusia diberi mandat untuk memiliki kualitas spiritual, intelektual, emosional, kehendak, dan fisik yang baik. Tugas kedua adalah memenuhi dan menaklukkan bumi dan menguasai apa yang ada di dalamnya. Ada hubungan yang tidak terpisahkan antara tugas pertama dan kedua. Dengan bertambahnya keturunan manusia yang "benar-benar", diharapkan daerah yang kosong dapat dihuni, dikendalikan dan dipelihara. Mereka harus peduli terhadap lingkungan tempat mereka tinggal. Menjaga agar tanah tetap baik dan subur, menjaga agar hewan tetap lestari. Keluarga dilihat dari perspektif pendidikan, bahwa keluarga adalah institusi pendidikan pertama dan utama dalam kehidupan manusia, kedua orang tua bertindak sebagai guru dan anak-anak mereka bertindak sebagai siswa.3

Semua tahu bahwa pendidikan sangat penting, sehingga karakter, perilaku, karakter dan pikiran menjadi lebih baik. Ada pepatah yang mengatakan "Menuntut ilmu di negeri China". Ini menunjukkan betapa pentingnya pendidikan, meskipun Anda harus bekerja keras dan harus melakukan perjalanan jauh. Namun nantinya akan merasakan manisnya hasil dari semua itu.

\footnotetext{
${ }^{1}$ Ahmad Saebani, Perkawinan dalam Hukum Islam dan Undang-Undang (Perspektif Figh Munakahat dan Undang-Undang Nomor 1/1974 tentang Poligami dan Problematikanya), 195.

2 Hawari, al Quran, Ilmu Kedokteran dan Kesehatan Jiwa, 161-62.

${ }^{3}$ Djamaluddin, Dinamika Pendidikan Islam, 139.
} 
William J. Goode berpendapat, bahwa keberhasilan: atau prestasi yang dicapai oleh siswa dalam pendidikan mereka tidak hanya menunjukkan kualitas lembaga pendidikan. Tetapi itu juga menunjukkan keberhasilan keluarga dalam memberi anak-anak mereka persiapan yang baik untuk pendidikan yang mereka jalani. Keluarga adalah institusi sosial yang ada di setiap masyarakat. Karena itu, keluarga menjadi institusi terkuat yang dimiliki oleh masyarakat manusia. Karena melalui keluarga seseorang mendapatkan kemanusiaannya. ${ }^{4}$

John Locke berpendapat, posisi pertama dalam mendidik seseorang terletak pada keluarga. Melalui konsep "tabula rasa", John Locke menjelaskan, bahwa seorang individu bagaikan kertas yang memiliki pola dan tergantung pada orang tua (keluarga) bagaimana mengisi kertas kosong sejak bayi. Melalui perawatan, perawatan dan pengawasan yang konstan, kepribadian dan kepribadian anak terbentuk. Dengan instingnya, bukan dengan teori, orang tua mendidik dan mengasuh keluarga. ${ }^{5}$

Tugas keluarga sangat mendesak, yaitu menciptakan suasana dalam proses keluarga melanjutkan pendidikan (progress berkelanjutan) dalam rangka melahirkan generasi penerus (keturunan) yang cerdas dan bermoral (berkarakter baik). Baik di mata orang tua, maupun masyarakat. Yayasan dan yayasan yang kuat adalah awal pendidikan dalam keluarga, landasan yang kuat dalam menginjak kehidupan yang lebih berat dan lebih luas untuk perjalanan selanjutnya anak-anak manusia.

Sebagaimana telah dijelaskan oleh Allah. di kitab suci Al-Qur'an, terdaftar di Q.S. al-Nisa / 4: 58; at-Tahrim / 56: 6; Hud / 11: 46; al-Anfal / 8: 28; al-Kahf / 18: 48, di mana ayat-ayat menyiratkan pentingnya mendidik anak dalam lingkup keluarga. Lingkungan keluarga dapat memainkan peran penuh dalam pengembangan keluarganya untuk menyediakan sistem pendidikan yang komprehensif dan saling berkelanjutan, dari anak-anak yang tumbuh dari periode pengembangan, hingga memasuki masa dewasa dan memasuki pernikahan, tetapi sekarang banyak orang tua sibuk dengan tugas kerja mereka, jadi tugas utama adalah memperhatikan perkembangan anaknya, ketika keluarga habis dengan kegiatan di luar rumah sehingga perhatiannya dalam keluarga disita, waktu yang harus diarahkan ke keluarganya terabaikan, sehingga kesibukan keluarga di luar rumah, sulit untuk memperhatikan perkembangan anak yang mengakibatkan banyak anak mengalami masalah dan mengalami gangguan psikologis, kebanyakan anak yang mengalami masalah, itu sangat besar pengaruhnya dari masalah lingkungan keluarga. Berdasarkan alasan di atas, fokus masalah saya dalam makalah ini adalah:

\footnotetext{
${ }^{4}$ Goode, The Family, diterjemahkan oleh Laila Hanom Hasyim dengan judul Sosiologi Keluarga, 5.

${ }^{5}$ Mahmud, Pendidikan Agama Islam dalam Keluarga, 135.
} 
Bagaimana Peran Lingkungan Keluarga dalam Perkembangan Anak di era kosmopolitan

\section{KAJIAN TEORI}

\section{Pengertian Keluarga}

Menurut Munandar; keluarga dalam arti sempit kata adalah kelompok sosial terkecil dari komunitas yang dibentuk oleh perkawinan dan terdiri dari seorang suami (ayah), istri (ibu) dan anak-anak mereka. Sedangkan keluarga dalam arti kata yang lebih luas, misalnya keluarga RT, keluarga yang kompleks atau keluarga Indonesia. ${ }^{6}$

Padahal menurut Mudjiono, et.al: Keluarga adalah payung hidup bagi seorang anak. Keluarga adalah tempat paling nyaman untuk seorang anak. ${ }^{7}$ Dengan demikian dapat dipahami bahwa fungsi keluarga bukan hanya tempat / tempat perlindungan tetapi keluarga adalah tempat untuk semua perasaan yang akan diperoleh dengan pelayanan yang baik oleh anak, suami / istri dan semua anggota keluarga. Keluarga yang baik dapat mentransfer perilaku, nilainilai dan informasi yang baik kepada anak-anak mereka dan semua anggota di lingkungan keluarga mereka

\section{Pengertian Pendidikan Keluarga}

Dalam berbagai literatur, para ahli memberikan berbagai perspektif tentang pengertian pendidikan keluarga. Misalnya Mansur, mendefinisikan pendidikan keluarga adalah proses memberi nilai positif bagi pertumbuhan dan perkembangan anak-anak sebagai landasan pendidikan lanjutan. ${ }^{8}$ Selain itu, Abdullah juga mendefinisikan pendidikan keluarga sebagai semua upaya yang dilakukan oleh orang tua dalam bentuk habituasi dan improvisasi untuk membantu mengembangkan kehidupan pribadi mereka. ${ }^{9}$

Ki Hajar Dewantara adalah salah satu pemimpin pendidikan Indonesia, juga menyatakan bahwa lingkungan keluarga untuk setiap orang (anak) adalah bidang pendidikan awal. Untuk pertama kalinya, orang tua (ayah dan ibu) ditempatkan sebagai pemandu (guru), sebagai instruktur, sebagai pendidik, mentor dan sebagai pendidik utama untuk anak-anak. Jadi tidak berlebihan bila mengacu pada pendapat para ahli di atas konsep pendidikan keluarga. Bukan hanya tindakan (proses), tetapi hadir dalam praktek dan implementasi, yang dilakukan oleh orang tua (ayah-ibu) dengan nilai pendidikan dalam keluarga. ${ }^{10}$

\footnotetext{
${ }^{6}$ Utami, Emansipasi dan Peran Ganda Wanita Indonesia. Suatu Tinjauan Psikologis.

${ }^{7}$ Mudjiono, Fungsi Keluarga Dalam Meningkatkan Sumber Daya Manusia.

${ }^{8}$ Mansur, Pendidikan Anak Usia Dini dalam Islam, 319.

${ }^{9}$ Abdullah, Pendidikan Keluarga Bagi Anak, 232.

${ }^{10}$ Dewantara, Ilmu Pendidikan, 255.
} 
Harap dicatat, mayoritas orang tua tidak tahu bagaimana konsep pendidikan keluarga. Hal ini tidak diperhatikan oleh orang tua (ayah dan ibu) dalam praktek sehari-hari mereka. Mereka telah menjalankan fungsi keluarga dalam pendidikan anak-anak. Intinya, fungsi keluarga adalah sebagai pendidikan karakter, sosial, kewarganegaraan, pembentukan kebiasaan dan pendidikan intelektual anak. Fungsi keluarga menurut Berns, yaitu: (a) fungsi reproduksi, (b) melaksanakan pendidikan dan sosialisasi di masyarakat, (c) membangun aturan sosial, (d) melaksanakan tindakan ekonomi, dan (e) membangun dan mendukung emosi anak-anak anak-anak perkembangan. ${ }^{11}$

\section{Tanggung Jawab Orang Tua}

Pasal 1 Undang-undang Perkawinan No. 1 tahun 1974, mengatakan:

Pernikahan adalah ikatan jasmani dan rohani antara seorang pria dan seorang wanita sebagai suami dan istri dengan tujuan untuk membentuk keluarga yang bahagia dan sejahtera berdasarkan Satu Ketuhanan. Anak yang lahir dari pernikahan ini adalah anak yang sah dan merupakan hak dan tanggung jawab kedua orang tua untuk menjaga dan mendidik mereka sebaik mungkin. Kewajiban orang tua untuk mendidik anak ini terus berlanjut sampai dia menikah atau bisa berdiri sendiri. ${ }^{12}$

Zakiah Daradjat mengatakan bahwa orang tua adalah pendidik utama dan pertama bagi anak-anak mereka, karena dari mereka anak-anak pertama menerima pendidikan. Dengan demikian bentuk pendidikan pertama adalah dalam kehidupan keluarga. ${ }^{13}$

Dari dua dasar di atas, itu menunjukkan seberapa besar tanggung jawab orang tua terhadap anak. Lebih tegas lagi Allah SWT menjelaskan tentang kewajiban mendidik anak ini di Surat At-Tahrim ayat 6 yang berbunyi:

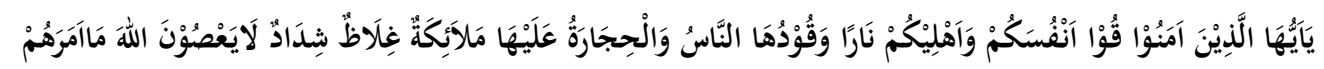

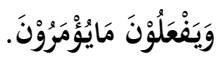

Artinya: "Hai orang-orang yang beriman! Jagalah dirimu dan keluargamu dari api neraka yang bahan bakarnya manusia dan batu, penjaga malaikat kasar dan keras, yang tidak memberontak melawan Allah apa yang Dia perintahkan kepada mereka dan selalu melakukan apa yang diperintahkan. (Q.S. At- Tahrim/66: 6). ${ }^{14}$

Ayat ini menyiratkan "perintah" atau fi'il amar yang merupakan kewajiban yang harus dipenuhi oleh kedua orang tua dari anak-anak mereka. Oleh karena itu, kedua orang tua harus dapat memainkan peran penting

\footnotetext{
${ }^{11}$ Berns, Child, Family, School, Community Socilization and Support, 89-90.

12 Ihsan, Dasar-dasar Kependidikan, 62.

${ }^{13}$ Daradjat, Peranan Agama dalam Kesehatan Mental, 35.

14 Departemen Agama RI, Al-Qur'an Tajwid dan Terjemahnya, 560.
} 
sebagai pendidikan pertama dan terdepan bagi anak-anak mereka, sebelum pendidikan anak-anak diserahkan kepada orang lain.Menurut Fuad Ihsan, tanggung jawab pendidikan oleh kedua orangtua meliputi:

a) Memelihara dan membesarkannya. Tanggung jawab ini adalah dorongan alami untuk dilaksanakan, karena anak-anak membutuhkan makanan, minuman dan perawatan, sehingga mereka dapat hidup secara berkelanjutan.

b) Melindungi dan menjamin kesehatannya, baik secara fisik maupun spiritual dari berbagai penyakit atau bahaya lingkungan yang dapat membahayakan dirinya.

c) Mendidiknya dengan berbagai pengetahuan dan keterampilan yang berguna untuk hidupnya, sehingga ketika ia tumbuh dewasa ia mampu berdiri sendiri dan membantu orang lain serta menjalankan fungsi kekhalifahan.

d) Membahagiakan anak-anak untuk dunia dan akhirat dengan memberi mereka pendidikan agama sesuai dengan tuntunan Tuhan sebagai tujuan akhir kehidupan Muslim. Tanggung jawab ini juga dikategorikan sebagai tanggung jawab kepada Allah. ${ }^{15}$

Agar tanggung jawab orang tua dalam pendidikan anak-anak terwujud, perlu diupayakan dengan berbagai cara, termasuk:

a) Kesadaran orang tua tentang tanggung jawab pendidikan dan membina anak terus menerus.

b) Orang tua perlu dilengkapi dengan teori pendidikan atau cara mendidik anak.

c) Selain itu orang tua perlu juga meningkatkan pengetahuan dan keterampilan mereka sebagai pendidik pertama dan utama untuk anakanak mereka, dengan cara belajar terus menerus.

\section{Peran Keluarga Dalam Perkembangan Mendidik Anak}

Keluarga untuk anak adalah lembaga pendidikan non-formal pertama, di mana mereka tinggal, berkembang, dan dewasa. Dalam sebuah keluarga,seorang anak pertama kali diajarkan dalam pendidikannya. Dari pendidikan di keluarga anak-anak mendapatkan pengalaman, kebiasaan, keterampilan dalam berbagai sikap dan berbagai macam pengetahuan. Menurut Effendi, keluarga memiliki peran utama dalam merawat anak-anak, dalam semua norma dan etika yang berlaku dalam masyarakat, dan budaya dapat diwariskan dari orang tua kepada anak-anak dari generasi yang disesuaikan dengan perkembangan masyarakat. ${ }^{16}$

\footnotetext{
15 Ihsan, Dasar-dasar Kependidikan, 94.

${ }^{16}$ Effendi, Wijaya, dan Hadi, Fungsi Keluarga Dalam Meningkatkan Kualitas Sumber Daya Manusia.
} 
Keluarga memiliki peran penting dalam meningkatkan kualitas sumber daya manusia. Pendidikan moral dalam keluarga perlu ditanamkan di awal setiap individu. Namun, selain tingkat pendidikan, semangat individu juga menjadi tolok ukur keberhasilan atau kegagalan pembangunan.

\section{Tantangan dalam mendidik anak-anak}

Dalam upaya menerapkan pendidikan anak-anak Islam, tidak akan lepas dari berbagai tantangan yang akan dihadapi. Namun semua tantangan ini bukan hambatan untuk mendidik anak-anak dalam Islam. Berbagai tantangan harus dianggap sebagai hiasan dalam perjuangan, sehingga upaya yang dilakukan dalam pendidikan anak akan lebih serius dalam berbagai cara.

Tantangan dalam pendidikan anak dapat dibagi menjadi dua, yaitu tantangan yang berasal dari dalam (internal) dan dari luar (eksternal). Kedua tantangan ini saling mempengaruhi dalam upaya pendidikan anak-anak. Sumber utama tantangan internal adalah orang tua anak itu sendiri. Banyak orang tua yang kekurangan materi dan tidak mengerti bagaimana mendidik anak-anak. Situasi akan menjadi rumit jika keharmonisan rumah tangga terganggu. Meskipun anak-anak membutuhkan tempat yang aman untuk perkembangan fisik, mental, dan pikiran mereka.

Tantangan lain bisa datang dari anggota keluarga. Orang tua mungkin telah mencoba untuk mendidik anak-anak mereka sebaik mungkin, tetapi intervensi dari anggota keluarga dapat merusak atmosfer. Kasus yang umum terjadi adalah sikap kakek-nenek yang selalu memanjakan anak. Akibatnya, anak-anak menjadi lebih dekat dengan kakek-nenek mereka, dan menganggap orangtua mereka terlalu membatasi diri. Hal yang sama berlaku antara ayah dan ibu. Ini sering terjadi ketika seorang ayah menegur si anak karena melakukan tindakan yang tidak benar, maka sang ibu muncul sebagai pembela, atau sebaliknya, akibatnya sianak merasa dia mendapat pembelaan dan dukungan, sehingga si anak merasa dia telah " dukungan "untuk mengulang tindakannya.

Tantangan eksternal lebih luas cakupannya. Berbagai informasi akan mempengaruhi perkembangan anak-anak dari berbagai sisi. Tantangan pertama berasal dari komunitas. Interaksi anak dengan lingkungan tidak dapat dihindari, anak-anak membutuhkan teman bermain dan teman sebaya yang dapat diundang untuk diajak bicara. Di satu sisi, informasi yang diterima akan dicatat. Lingkungan rumah yang jauh dari nilai-nilai Islam dapat meringankan pendidikan yang diinvestasikan di rumah. Seorang ibu mungkin terkejut mendengar anaknya mengucapkan kata-kata yang tidak pantas. Setelah menyelidiki, ternyata anak itu meniru kata-kata temannya yang orangtuanya sering bertengkar. Proses menyerap informasi ini sering dialami 
oleh anak-anak yang belum mengerti apa-apa. Mereka sangat cepat meniru berbagai kata yang didengarnya.

Lingkungan sekolah bisa menjadi sumber tantangan kedua. Namun, para guru di sekolah tidak akan dapat mengawasi siswa mereka kapan saja. Interaksi anak dengan teman-teman di sekolah yang memiliki perilaku bervariasi, jika tidak diawasi dengan baik oleh guru sebagai orang yang bertanggung jawab atas pendidikan sekolah, dapat memiliki dampak negatif. Perkelahian mahasiswa adalah salah satu contoh ekses dari dampak negatif ini. Terutama dengan kecenderungan beberapa keluarga Muslim di kota-kota besar untuk mengirim anak-anak mereka ke sekolah-sekolah non-Muslim. Maka bukan hanya moralitas yang terpapar polusi, aqidah mereka akan berangsur-angsur terputus. Paling tidak, yang keluar dari mereka adalah anakanak Islam yang tidak tahu agama mereka secara keseluruhan, tetapi telah terkontaminasi oleh ajaran-ajaran non-Islam. Hal ini tentu sangat berbahaya, karena akan membentuk generasi Muslim yang tipis dalam iman, jadi bahkan jika aqidah mereka tidak secara formal bergerak, pemikiran mereka tentang agama mereka menjadi kabur, karena mereka telah dikotori dengan berbagai pemahaman yang berasal dari luar ajaran Islam.

Tantangan eksternal berikutnya datang dari media massa. Media massa merupakan sumber tantangan yang sangat sulit diantisipasi. Informasi yang dilemparkan oleh media massa, baik cetak maupun elektronik, memiliki daya tarik yang kuat. Jika tidak ada arahan dari orang tua, anak akan menyerap semua informasi tanpa terkendali. Kami semua prihatin, dengan berbagai program hiburan yang ditawarkan oleh media massa, khususnya media elektronik, yaitu televisi. Tidak ada batasan usia untuk audiens untuk setiap program televisi. Akibatnya, itu juga seperti pernikahan dini, film India dan Latin yang dikonsumsi oleh semua kelompok umur. Pendidik di negara itu telah kesal dengan siaran televisi. Bukan hanya karena puisi dan cerita yang tidak cocok untuk konsumsi anak-anak, tetapi juga cara berpakaian para entertainer yang sangat tidak pantas. Film-film yang disajikan kepada anakanak sangat mengkhawatirkan dan dapat mengganggu fikih dan moralitas. Barat dan India dan Cina menyerang dengan film-film super, pamer dan keintiman pria dan wanita. Sementara produk lokal tidak mau kalah dengan membawa anak-anak ke kehidupan yang penuh mistisisme, filosofi dan takhayul, serta dengan film-film yang menunjukkan keaslian dan keintiman pria dan wanita. Kalaupun ada acara anak-anak, ternyata ada juga banyak yang tidak baik untuk pendidikan anak-anak, katakanlah salah satu contoh film anak-anak yang sangat populer, yaitu Shin Chan. Ternyata ceritanya lebih banyak bercerita tentang seorang anak yang nakal, tidak sopan dan bertindak sesuka hati dari nilai-nilai pendidikan. Ditambah dengan tayangan iklan yang mengomersialkan tubuh perempuan lebih banyak, meski seringkali tidak 
sesuai dengan tujuan iklan. Ini hanya dari televisi, belum dari sumber media lain. Banyak stasiun radio dan majalah yang menawarkan pola hidup jahiliyyah kepada anak-anak kita.

\section{PEMBAHASAN}

1. Tafsir Jalalain

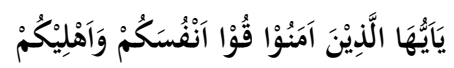

(Hai orang-orang yang beriman, peliharalah diri kalian dan keluarga kalian) dengan mengarahkan mereka kepada jalan ketaatan kepada Allah.

نَارًا وَقُوْدُدهَا النَّاسُ

(dari api neraka yang bahan bakarnya adalah manusia) orang-orang kafir.

وَالْحِجَارَة

(dan batu) seperti berhala yang mereka sembah adalah bagian dari bahan bakar neraka. Atau dengan kata lain api neraka sangat panas, sehingga bendabenda bisa terbakar. Berbeda halnya dengan api di dunia, karena api di dunia diekspresikan oleh kayu dan lain-lain.

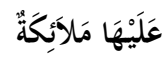

(penjaganya malaikat-malaikat) yaitu penjaga neraka adalah para malaikat dengan sembilan belas malaikat.

(yang kasar) Artinya, hatinya kasar.

(yang keras) sangat keras hantamannya.

لَاَيَعْصُوْنَ اللهَ مَاَمَرَهُمْ

(Mereka tidak pernah tidak taat kepada Allah dalam apa yang Dia perintahkan kepada mereka) - para malaikat penjaga neraka tidak pernah tidak mematuhi perintah Allah.

$$
\text { وَيَفْعَلُوْنَ مَايُوَْْرُوْنَنَ }
$$

(dan mereka selalu melakukan apa yang diperintahkan) kalimat ini didasarkan pada Badal dari pernyataan sebelumnya. Dalam ayat ini ada ancaman bagi orang percaya untuk tidak murtad; dan juga ayat ini adalah ancaman bagi orang-orang munafik, mereka yang mengaku percaya dalam bahasa mereka tetapi hati mereka masih tidak percaya. ${ }^{17}$

${ }^{17}$ Al Mahalli dan As Suyuthi, Tafsir Jalalain. Terj. Bahrun Abu Bakar, Lc, 2489-90. 


\section{Tafsir Ibnu Katsir}

Mengenai firman Allah قُؤا آنْفُسَكُمْ وَاَهْليْكُمْ نَارًا (Jaga dirimu dan keluargamu dari api neraka), Mujahid berkata: "Takutlah kepada Allah dan nasihatkan keluargamu untuk berhati-hati kepada Allah." Sementara Qatadah mengatakan: "Yaitu, Anda harus memerintahkan mereka untuk mematuhi Allah dan untuk mencegah mereka dari pemberontakan kepada-Nya. Dan Anda harus mematuhi perintah Tuhan dan memerintahkan mereka untuk menjalankannya, dan membantu mereka dalam melakukannya. Jika Anda melihat mereka melakukan ketidaktaatan kepada Tuhan, peringati mereka dan cegah mereka. "Demikian pula, adh Dhahhak dan Muqatil bin Hayyan, di mana mereka mengatakan:" Setiap Muslim wajib untuk mengajar keluarganya, termasuk kerabat dan budaknya, -bahwa Tuhan mewajibkan mereka dan apa yang dia larang. ${ }^{18}$

\section{Tafsir Fi Dzilalil Qur’an}

a. قوا انفسكم (at-Tahrim/66: 6)

Secara linguistik, kata quu anfusakum terdiri dari dua suku kata, yaitu kata qu yang merupakan bentuk amr lil jama '(kata perintah untuk jamak) dari waqa yang berarti merawat Anda, dan kata anfusakum yang berarti Anda. Dengan demikian, kata qu anfusakum dalam konteks ayat ini berarti perintah untuk selalu menjaga diri sendiri dan keluarga dari api neraka.

b. غلاظ شداد (at-Tahrim/66: 6)

Secara linguistik, kata ghiladz syidad terdiri dari dua suku kata, yaitu kata ghiladz yang merupakan bentuk jamak dari kata galiz, yang berarti keras, dan kata syidad yang merupakan bentuk jamak dari kata syadid, yang berarti kasar. Dengan demikian, kata gilaz syadid dalam konteks ayat ini adalah deskripsi dari sifat malaikat yang menjaga neraka yang sangat keras dan kasar dalam menyiksa penghuni neraka

Dalam ayat ini, Allah memerintahkan orang-orang percaya untuk menjauhkan diri dari api neraka yang bahan bakarnya terdiri dari manusia dan batu, patuh dan patuh melaksanakan perintah Allah swt. Mereka juga diperintahkan untuk mengajar keluarga mereka untuk mematuhi dan mematuhi perintah Allah untuk menyelamatkan mereka dari api neraka. Keluarga adalah mandat yang harus dijaga baik untuk kesejahteraan fisik maupun spiritual. Di antara cara-cara untuk menyelamatkan diri dari api adalah dengan mendirikan doa dan bersabar. ${ }^{19}$ Seperti firman Allah swt.

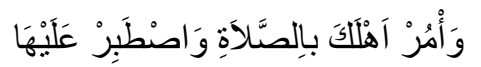

\footnotetext{
18 bin Muhammad Alu Syaikh, Tafsir Ibnu Katsir, 35.

${ }^{19}$ Quthb, Tafsir Fi Dzilalil Qur'an, 204.
} 
Dan perintahkanlah keluargamu melaksanakan shalat dan sabar dalam mengerjakannya. (Taha/20: 132) ${ }^{20}$

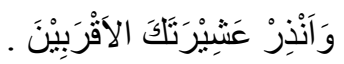

Dan berilah peringatan kepada kerabat-kerabatmu (Muhammad) yang terdekat. (Asy-Syura/26: 214) ${ }^{21}$

\section{Tafsir Al Misbah}

Dalam suasana peristiwa yang terjadi di rumah tangga Nabi. sebagaimana diuraikan oleh ayat-ayat sebelumnya, ayat di atas memberikan petunjuk kepada orang-orang percaya bahwa: Hai orang yang beriman, jaga dirimu di antara yang lain dengan meniru Nabi. dan jagalah keluargamu yaitu istri, anak-anak dan semua yang berada di bawah tanggung jawabmu dengan membimbing dan mendidik mereka sehingga kamu semua terhindar dari api neraka yang bahan bakarnya adalah manusia kafir dan juga batu-batu di antara yang lainnya yang dijadikan berhala. Dialah yang berurusan dengan neraka dan ditugasi menyiksa para penghuni malaikat-malaikat keji dan tindakan-tindakan mereka, yang diperlakukan dengan ketat dalam melaksanakan tugas penyiksaan, yang tidak menaati Allah tentang apa yang telah Dia perintahkan kepada mereka sehingga Hukuman mereka Jatuhkan bahkan jika mereka kasar - tidak kurang atau kurang dari apa yang diperintahkan Tuhan, sesuai dengan dosa dan kesalahan penghuni neraka dan mereka juga selalu dan dari waktu ke waktu bekerja dengan mudah apa yang Tuhan perintahkan kepada mereka. Dalam penyiksaan, para malaikat selalu berkata: Wahai orang-orang tidak percaya yang menolak untuk mengakui bimbingan Allah dan Rasul-Nya, jangan meminta demi meminta dalih untuk memperbaiki kesalahan dan penyiksaan Anda hari ini. Karena sudah tidak ada waktu lagi untuk meminta maaf atau pertengkaran, ini adalah saat jatuhnya sanksi, memang Anda saat ini hanya dihargai sesuai dengan apa yang Anda dulu ketika Anda hidup di dunia selalu lakukan.

Ayat 6 di atas menggambarkan bahwa dakwah dan pendidikan harus dimulai dari rumah. Ayat-ayat di atas adalah redaksional pada pria (ayah), tetapi itu tidak hanya berarti bagi mereka. Ayat ini berhubungan dengan wanita dan pria (ayah dan ibu) sebagai ayat yang sama (seperti mereka yang memesan puasa) yang juga dimaksudkan untuk pria dan wanita. Ini berarti kedua orang tua bertanggung jawab atas anak-anak dan pasangannya masingmasing karena masing-masing bertanggung jawab atas perilaku mereka. Ayah atau ibu saja tidak cukup untuk menciptakan rumah tangga yang ditutupi oleh nilai-nilai agama dan dibayangi oleh hubungan yang harmonis. Malaikat yang dituduh غلاظ (kasar) tidak kasar dari sifat fisik mereka seperti dalam beberapa

\footnotetext{
${ }^{20}$ Hatta, Tafsir Qur'an Per Kata Dhilengkapi dengan Asbabun Nuzul \& Terjemah, 321.

${ }^{21}$ Hatta, 375.
} 
interpretasi, karena malaikat adalah makhluk halus yang diciptakan dari cahaya. Atas dasar ini, kata harus dipahami dengan cara kasar dari pidatonya. Mereka telah menciptakan Tuhan yang khusus untuk menghadapi neraka. "Hati" mereka tidak tidak wajar atau tersentuh oleh erangan, tangisan atau belas kasih, mereka diciptakan oleh Allah dengan sifat sadis, dan itu mereka (شداد) syidad / keras, makhluk yang keras hati dan kerja keras. ${ }^{22}$

\section{Tafsir Al Azhar}

Setelah Tuhan memberi petunjuk tentang rumah tangga Rasulullah, maka Tuhan memperlihatkan panggilan-Nya kepada orang percaya bagaimana sikap mereka dalam menegakkan rumah tangga. "Hai kamu yang percaya Jaga dirimu dan keluargamu dari api neraka."

Di dasar ayat ini jelas bahwa hanya mengakui iman saja tidak cukup. Iman harus dipupuk dan dipelihara, terutama dengan dasar iman untuk membuat orang-orang aman dan rumah tangga dari api neraka. Alat-alatnya adalah manusia dan batu. Batu-batu itu adalah barang berharga yang dibuang dan menyebar ke mana-mana. Batu itu akan digunakan sebagai kayu api. Manusia Allah yang tidak patuh, yang hidup di dunia ini tidak berharga karena telah dipenuhi dengan dosa, sama dengan bebatuan yang tersebar di tengahtengah pasir. "Di atas adalah malaikat yang kejam dan keras kepala". Disebut atasnya karena Tuhan memberikan kekuatan kepada para malaikat untuk menjaga dan mengendalikan neraka, sehingga api selalu menyala, sehingga penjual selalu siap, baik batu atau manusia. ${ }^{23}$ Ujung ayat menunjukkan bagaimana keras disiplin dan peraturan yang dijalankan dan dijaga oleh malaikat-malaikat itu. Nampaklah bahwa mereka semuanya hanya sematamata menjalankan perintah Allah dengan patuh dan setia, tidak membantah.

Dari rumah tangga itu mulai menanamkan Iman dan menumbuhkan Islam. Karena rumah tangga itu akan terbentuk rakyat. Dari dalam komunitas itu akan menjunjung komunitas Muslim. Komunitas Muslim adalah masyarakat yang memiliki pandangan hidup serupa, setara dengan penilaian terhadap Islam. Karena itu, orang percaya tidak boleh pasif, artinya tetap diam dan menunggu. Nabi telah menjelaskan tanggung jawab menegakkan Iman sesuai dengan Hadis Shahih diriwayatkan oleh Bukhari Muslim. Agar diri seseorang menjadi berpengaruh, berwibawa, dihormati, berperilaku dan berperilaku sebagai teladan oleh anak dan istrinya. Dia harus sangat bangga dan luar biasa untuk keluarga. Dan itu tidak cukup, biarkan dia membimbing istrinya, pimpin dia. Setelah kalimat perintah bagi orang percaya untuk melindungi diri mereka sendiri dan anggota-anggotanya dari nyala api ini turun, tanyakan Sayyidina Umar bin Khattab kepada Rasulullah saw. : "Kami

\footnotetext{
${ }^{22}$ Shihab, Tafsir Al Misbah: Pesan, Kesan, dan Keserasian Al-Qur'an, 14:178.

${ }^{23}$ Hamka, Tafsir Al-Azhar Juz XXVIII, 309.
} 
telah menahan diri dari api, dan bagaimana kami menjaga ahli kami dari neraka?"

Rasulullah saw. menjawab:

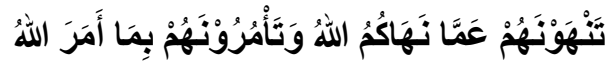

“Anda melarang mereka dari semua perbuatan yang Allah melarang Anda dan memerintahkan mereka untuk melakukan apa yang diperintahkan Allah ". (H.R. Al-Qusyairi, dalam tafsir Al-Qurthubi)

Selanjutnya, ketika kedua suami dikaruniai anak-anak Tuhan, adalah kewajiban bagi ayah untuk memilih nama baik untuknya, untuk mengajarinya menulis dan membaca, dan jika waktunya telah tiba, itu akan cepat membuat kekuatan seorang pria. dan ketekunan jika itu wanita. Seperti yang telah kami katakan sejak awal, dari rumah tangga, atau dari kehidupan gabungan suami dan istri bahwa orang-orang akan terbentuk. Suami mendirikan rumah, anakanak dan cucu yang lebih rendah, yang dimiringkan oleh pelayan dan nelayan.

Inilah yang diancam dengan api neraka, yang akan diterangi oleh manusia dan batu, dijaga, dan dikendalikan oleh malaikat yang kasar dan gerak tubuhnya, tidak pernah mengubah apa yang Tuhan perintahkan dan harus lakukan apa yang diperintahkan. ${ }^{24}$

\section{Tafsir al-Qurthubi}

Abi Abdillah Muhammad bin Ahmad al-Anshari al-Qurthubi, dalam AlJami'u li Ahkami Al-Qur'an menjelaskan bahwa dalam firman Allah ini (QS atTahrim ayat 6) ada masalah, yaitu urutan laki-laki untuk mempertahankan dirinya dan keluarganya dari neraka. Itu berarti seseorang harus meningkatkan dirinya dengan melakukan ketaatan, dan juga memperbaiki keluarganya. Ali bin Abi Thalhah diriwayatkan dari Ibn 'Abbas: "Jagalah jiwa Anda dan instruksikan keluarga Anda untuk mendiktekan dan berdoa, sehingga Allah akan memelihara mereka karena Anda (dari api neraka). Para ulama sepakat untuk mengatakan bahwa dalam ayat itu, anak itu termasuk di dalamnya, karena anak itu adalah bagian darinya. Jadi, seseorang harus mengajari anaknya sesuatu yang halal dan haram, serta menjauhkannya dari ketidakpatuhan dan dosa, serta hukum lainnya.. ${ }^{25}$

7. Tafsir al-Wasith

Wahbah Zuhaili dalam buku At-Tafsir al-Wasith menjelaskan bahwa, dalam kata-kata Allah (QS at-Tahrim ayat 6) itu berarti: "Wahai mereka yang membenarkan Allah dan Rasul-Nya, latihlah dirimu dan keluargamu (untuk memenuhi mereka Perbuatan baik.) Buatlah perlindungan bagi kalian semua dari api neraka, untuk diri mereka sendiri dengan membuatnya selalu taat kepada Allah SWT, sedangkan untuk keluarga dengan memberi nasihat

${ }^{24}$ Hamka, 314.

${ }^{25}$ Al-Qurthubi, Tafsir Al-Qurthubi terjemahan. Faturrahman, dkk, 744. 
kepada mereka dan juga mendorong mereka untuk melakukan ketaatan. mereka tidak akan jatuh ke dalam api neraka yang mengerikan, diterangi oleh manusia dan batu. Ini adalah sebuah proposisi bahwa seorang guru harus tahu apa yang dia perintahkan dan dilarang.

Ibn Jarir berkata, adalah tugas kita untuk mengajarkan agama dan kebaikan sopan santun, etika dan tata krama yang mutlak diperlukan untuk anakanak kita.. ${ }^{26}$

\section{PENUTUP}

Berdasarkan uraian di atas dapat disimpulkan bahwa Dari penjelasan di atas, dapat dipahami bahwa keluarga dalam perspektif Islam memiliki peran dan tanggung jawab yang sangat penting dan strategis dalam proses membina dan mendidik anak-anak. Karena keluarga adalah lembaga pendidikan pertama bagi anak-anak mereka. Ayah menjadi seorang pendidik dan juga seorang ibu yang dekat dengan anak-anaknya. Tugas dan tanggung jawab keluarga dalam pendidikan anak mencakup semua hal, baik yang berkaitan dengan anak-anak di rumah atau di luar rumah. Kedua anak itu sejak ia masih kecil bahkan sampai ia mencapai usia dewasa. Peran dan tanggung jawab ini termasuk fisik, pendidikan spiritual, pembentukan moral dan intelektual, memperkuat spiritualitas anak-anak. Oleh karena itu, tidak mengherankan jika Islam menyiratkan bahwa kebaikan buruk suatu negara sangat bergantung pada keberhasilan keluarga dalam mendidik anak-anak mereka. Dalam proses pendidikan - termasuk pendidikan dalam keluarga - metode pendidikan diperlukan yang mampu menanamkan nilai-nilai pendidikan Islam kepada anak-anak, sehingga anak-anak tidak hanya tahu tentang nilai-nilai atau moral, tetapi juga mereka diharapkan dapat melaksanakan moralitas sebagai tujuan utama pendidikan Islam.

Selain itu, dapat disimpulkan isi Surat At Tahrim ayat 6 mengajarkan kita tentang:

a) Perintah Taqwa kepada Allah SWT dan berdakwah.

b) Ajakan untuk menyelamatkan diri dan keluarga dari api neraka

c) Pentingnya pendidikan Islam sejak usia dini

Dan untuk lebih meningkatkan pengetahuan kita, saya akan mengutip pernyataan ilmuwan pendidikan Dorothy Law Nolte yang pernah menyatakan bahwa anak-anak belajar dari lingkungan mereka. Isinya adalah sebagai berikut:

a. Jika anak-anak hidup dengan kritik, mereka belajar untuk mengutuk

b. Jika anak-anak hidup dengan permusuhan, mereka belajar untuk bertarung

c. Jika anak-anak hidup dengan ketakutan, mereka belajar menjadi khawatir

d. Jika anak-anak hidup dengan belas kasih, mereka belajar merasa kasihan pada diri mereka sendiri

${ }^{26}$ Zuhaili, Tafsir Al-Wasith terjemahan. Muhtadi,dkk, 679. 
e. Jika anak-anak hidup dengan cemoohan, mereka belajar merasa malu

f. Jika anak-anak hidup dengan cemburu, mereka belajar merasa cemburu

g. Jika anak-anak hidup dengan rasa malu, mereka belajar untuk merasa bersalah

h. Jika anak-anak hidup dengan dorongan, mereka belajar percaya diri

i. Jika anak-anak hidup dengan toleransi, mereka belajar kesabaran

j. Jika anak-anak hidup dengan pujian, mereka belajar apresiasi

k. Jika anak-anak hidup dengan penerimaan, mereka belajar untuk mencintai

l. Jika anak-anak hidup dengan persetujuan, mereka belajar menyukai diri mereka sendiri

m. Jika anak-anak hidup dengan pengakuan, mereka belajar itu baik untuk memiliki tujuan

n. Jika anak-anak hidup dengan berbagi, mereka belajar kemurahan hati

o. Jika anak-anak hidup dengan jujur, mereka belajar dengan jujur

p. Jika anak-anak hidup dengan keadilan, mereka belajar keadilan

q. Jika anak-anak hidup dengan kebaikan dan pertimbangan, mereka belajar untuk menghormati

r. Jika anak-anak hidup dengan keamanan, mereka belajar untuk memiliki keyakinan pada diri mereka sendiri dan orang-orang tentang mereka

s. Jika anak-anak hidup dengan persahabatan, mereka belajar bahwa dunia adalah tempat yang baik untuk hidup. ${ }^{27}$

\section{DAFTAR PUSTAKA}

Abdullah, M. Imron. Pendidikan Keluarga Bagi Anak. Cirebon: Lektur, 2003.

Ahmad Saebani, Beni. Perkawinan dalam Hukum Islam dan Undang-Undang (Perspektif Fiqh Munakahat dan Undang-Undang Nomor 1/1974 tentang Poligami dan Problematikanya). Bandung: Pustaka Setia, 2008.

Al Mahalli, Jalaluddin, dan Jalaluddin As Suyuthi. Tafsir Jalalain. Terj. Bahrun Abu Bakar, Lc. Kelima belas. Bandung: Sinar Baru Algesindo, 2016.

Al-Qurthubi, Syaikh Imam. Tafsir Al-Qurthubi terjemahan. Faturrahman, dkk. Jakarta: Pustaka Azzam, 2009.

Berns, Robert M. Child, Family, School, Community Socilization and Support. United State: Thomson Corporation, 2007.

Daradjat, Zakiah. Peranan Agama dalam Kesehatan Mental. Jakarta: Gunung Agung, 1973.

Departemen Agama RI. Al-Qur'an Tajwid dan Terjemahnya. Bandung: PT. Syaamil Cipta Media, 2006.

Dewantara, Ki Hajar. Ilmu Pendidikan. Yogyakarta: Taman Siswa, 1961.

Djamaluddin, Darwis. Dinamika Pendidikan Islam. Semarang: Rasail, 2006.

"Dorothy Law Nolte: Anak Belajar Dari Kehidupannya - DP3AKB Jabar." Diakses 29 Oktober 2018. http://bp3akb.jabarprov.go.id/dorothy-law-nolte-anakbelajar-dari-kehidupannya/.

27 "Dorothy Law Nolte." 
Effendi, Suratman, Ali Thaib Wijaya, dan B. Chasrul Hadi. Fungsi Keluarga Dalam Meningkatkan Kualitas Sumber Daya Manusia. Jambi: Departemen Pendidikan dan Kebudayan, 1995.

Goode, William J. The Family, diterjemahkan oleh Laila Hanom Hasyim dengan judul Sosiologi Keluarga. Jakarta: PT. Bumi Aksara, 1996.

Hamka. Tafsir Al-Azhar Juz XXVIII. Jakarta: Pustaka Panji Mas, 1985.

Hatta, Ahmad. Tafsir Qur'an Per Kata Dhilengkapi dengan Asbabun Nuzul \& Terjemah. Jakarta: Maghfirah Pustaka, 2011.

Hawari, Dadang. al Quran, Ilmu Kedokteran dan Kesehatan Jiwa. Yogyakarta: Dana Bakti Prima Press, 1997.

Ihsan, Fuad. Dasar-dasar Kependidikan. Jakarta: PT. Rineka Cipta, 1997.

Mahmud. Pendidikan Agama Islam dalam Keluarga. Jakarta: Akademia, 2013.

Mansur. Pendidikan Anak Usia Dini dalam Islam. Yogyakarta: Pusta Pelajar, 2005.

Mudjiono, Hermawan. Fungsi Keluarga Dalam Meningkatkan Sumber Daya Manusia. Yogyakarta: Departemen Pendidikan dan Kebudayan, 1996.

Mudzakir. Tafsir Tarbawi. Bogor: PT. Lintera Antar Nusa, 2009.

Muhammad Alu Syaikh, Abdullah bin. Tafsir Ibnu Katsir. 10 ed. Jakarta: Pustaka Imam Syafi'i, 2008.

Quthb, Sayyid. Tafsir Fi Dzilalil Qur'an. Jakarta: Gema Insani, 2001.

Shihab, M. Quraish. Tafsir Al Misbah: Pesan, Kesan, dan Keserasian AlQur'an. Baru. Vol. 14. Jakarta: Lentera Abadi, 2011.

Utami, Munandar. Emansipasi dan Peran Ganda Wanita Indonesia. Suatu Tinjauan Psikologis. Depok: UI Press, 1983.

Zuhaili, Wahbah. Tafsir Al-Wasith terjemahan. Muhtadi,dkk. 3 ed. Jakarta: Gema Insani, 2013. 